\title{
RESPON INVESTOR TERHADAP PENGUMUMAN LABA INDUSTRI PERBANKAN YANG MENGHADAPI KOS STICKINESS
}

\author{
Windyastuti, Kunti Sunaryo, Sri Hastuti \\ Departemen Akuntansi Fakultas Ekonomika dan Bisnis UPN "Veteran" Yogyakarta \\ Jl. SWK 104 (Lingkar Utara) Condongcatur Yogyakarta, 55283, Indonesia
}

\begin{abstract}
Keywords:

Cost Stickiness,

Financial Statement,

Earnings, Response

of Investors

JEL Classification:

D23, G21, G24

This study aimed to analyze the response of investors to the announcement of the financial statements of the banking sector. The population in this study was the banking industry. This study used purposive sampling method. Based on sampling techniques the number of samples in this study were 11 banks. The research period was 2002-2014. The analysis technique used was panel data regression. The result showed that investor response to the financial statements of banks which faced cost stickiness was weak. The increase of cost stickiness on banking sector led the weak investor response to the announcement of the financial statements of banks. In the banking companies facing cost stickiness problem, earnings prediction accuracy reduced. This causes the income statement would provide information that was less important to the earnings prediction in the next periods.
\end{abstract}

Kata kunci:

Kos Stickiness,

Laporan

Keuangan, Laba,

Respon Investor

\begin{abstract}
Abstrak
Penelitian ini bertujuan untuk menganalisis respon investor terhadap pengumuman laporan keuangan sektor perbankan. Populasi dalam penelitian ini adalah industri perbankan. Penelitian ini menggunakan metode purposive sampling. Berdasarkan teknik sampling jumlah sampel dalam penelitian sejumlah 11 bank. Periode penelitian tahun 2002-2014. Teknik analisis yang digunakan regresi berganda data panel. Hasil penelitian menunjukkan lemahnya respon investor terhadap laporan keuangan perbankan yang menghadapi kos stickiness. Kenaikan kos stickiness sektor perbankan menyebabkan lemahnya respon investor terhadap pengumuman laporan keuangan perbankan. Pada perusahaan perbankan yang menghadapi masalah kos stickiness, akurasi prediksi laba berkurang. Hal ini menyebabkan laba yang dilaporkan akan memberikan informasi yang kurang penting bagi prediksi laba periode mendatang.
\end{abstract}


Kos merespon secara asimetrik terhadap penurunan dan kenaikan volume aktivitas perusahaan. Kos meningkat secara lebih cepat pada saat volume aktivitas perusahaan mengalami kenaikan daripada saat volume aktivitas mengalami penurunan $(\mathrm{He}$, et al. 2010). Perilaku kos yang demikian ini disebut sticky. Kos stickiness ditandai dengan perbedaan slope kurva kos pada saat volume aktivitas perusahaan meningkat dan pada saat volume aktivitas perusahaan menurun (Anderson et al. 2007). Slope kurva kos pada saat volume aktivitas perusahaan menurun lebih kecil daripada slope kurva kos pada saat volume aktivitas meningkat.

Kos stickiness berkaitan dengan kemampuan perusahaan melakukan penyesuaian (adjustment) sumber daya. Pada saat aktivitas perusahaan turun, penyesuaian sumber daya berjalan lebih lambat dibandingkan penyesuaian pada saat penjualan meningkat. Hal ini dikarenakan manajer cenderung untuk tetap menggunakan sumber daya tak terpakai daripada melakukan pengurangan pada saat volume aktivitas menurun. Semakin besar kos stickiness, semakin besar pula biaya penyesuaian yang ditanggung perusahaan pada saat penjualan mengalami penurunan. Sebagai akibatnya perusahaan tidak bisa melakukan penghematan. Pada saat penjualan menurun, perusahaan dengan kos stickiness tinggi menunjukkan penurunan laba yang lebih besar daripada perusahaan dengan kos stickiness rendah (Kama \& Weiss, 2010).

Temuan dari beberapa penelitian terakhir menunjukkan pentingnya analisis perilaku kos stickiness dalam bidang akuntansi kos (Banker et al., 2011). Pengembangan studi perilaku kos telah menarik perhatian akuntan manajemen untuk mengkaji aspek pengendalian dan pengambilan keputusan. Akuntansi kos banyak membahas perilaku kos sebagai aspek dalam analisis laba, akan tetapi hubungan antara perilaku kos dengan prediksi laba belum banyak dibahas (Weiss, 2010).

Pengembangan konsep kos stickiness memberikan dasar bagi eksplorasi bagaimana perilaku kos berdampak pada akurasi prediksi laba. Faktor kos stickiness menyebabkan manajer mengalami kesulitan untuk menurunkan kos pada saat penjualan turun. Manajer harus menanggung kos penyesuaian (adjustment cost) akibat perubahan jumlah penggunaan sumber daya (Bon-Kim \& Wang, 2014). Kos stickiness berkaitan dengan akurasi prediksi laba. Prediksi laba tanpa mempertimbangkan aspek kos stickiness tidak akurat. Laba yang dilaporkan menjadi kurang informatif bagi prediksi laba periode yang akan datang. Kesalahan dalam prediksi baik pada saat aktivitas perusahaan meningkat maupun menurun, akan lebih besar pada perusahaan yang menghadapi kos stickiness. Variabilitas dari kesalahan prediksi akan meningkat seiring dengan peningkatan derajat kos stickiness. Dengan demikian semakin tinggi kos stickiness, semakin kecil akurasi prediksi laba.

Respon investor terhadap pengumuman laba perusahaan dengan kos stickiness tinggi akan berbeda dengan respon investor terhadap pengumuman laba perusahaan dengan kos stickiness rendah. Hal tersebut ditunjukkan oleh koefisien respon yang menurun (Weiss, 2010). Penurunan respon investor terhadap pengumuman laba mengindikasikan berkurangnya kepercayaan investor. Semakin tinggi kos stickiness, semakin rendah respon investor terhadap pengumuman laba. Kepercayaan investor terhadap informasi tentang laba semakin berkurang. Pelaku pasar merespon dengan lemah pengumuman laba dari perusahaan yang menghadapi kos stickiness.

Penelitian-penelitian tentang kos stickiness selama ini cenderung menggunakan industri manufaktur sebagai objek penelitian. Berbeda dengan penelitian sebelumnya, penelitian ini mengambil objek penelitian industri perbankan. Pemilihan perbankan sebagai obyek penelitian dikarenakan sektor tersebut berperan penting dalam perekonomian (Siringoringo, 2012). Di samping itu, dalam laporan laba rugi perbankan tidak dikenal kos pemasaran, sebagaimana terdapat dalam 


\section{Respon Investor terhadap Pengumuman Laba Industri Perbankan yang Menghadapi Kos Stickiness \\ Windyastuti, Kunti Sunaryo, \& Sri Hastuti}

laporan laba rugi perusahaan manufaktur. Selanjutnya penelitian ini menggunakan model dinamis guna memperbaiki model-model penelitian sebelumnya yang menggunakan model statis. Hal ini berdasarkan pertimbangan bahwa dalam ilmu ekonomi termasuk akuntansi, ketergantungan suatu variabel terikat atas variabel-variabel bebas jarang yang bersifat seketika. Sangat sering variabel terikat bereaksi terhadap variabel bebas dengan suatu selang waktu (lag). Dengan kata lain diwujudkan dalam suatu model dinamis.

Penelitian ini bertujuan untuk menganalisis respon investor terhadap pengumuman laporan keuangan sektor perbankan. Berdasar analisis ini akan dapat diketahui apakah investor yang mendapatkan informasi laba akan berperilaku berbeda apabila mengetahui adanya kos stickiness.

\section{METODE}

Objek penelitian ini adalah perusahaan-perusahaan perbankan yang go public di Bursa Efek Indonesia (BEI) selama periode 2002-2014. Dalam periode tersebut telah terjadi krisis ekonomi tahun 2008. Sebelum tahun 2008 perekonomian tidak mengalami krisis sehingga volume aktivitas perusahaan mengalami kenaikan. Adapun pada tahun 2008-2009 perekonomian mengalami krisis sehingga volume aktivitas beberapa perusahaan mengalami penurunan. Selanjutnya sejak tahun 2010 mulai terjadi pemulihan ekonomi sehingga volume aktivitas perusahaan kembali mengalami kenaikan. Dengan terdapatnya data pada saat volume aktivitas perusahaan naik dan data pada saat volume aktivitas perusahaan turun, maka kos stickiness dapat diidentifikasi.

Data yang digunakan adalah data sekunder yang diperoleh dari Indonesia Capital Market Directory (ICMD). Data penelitian mencakup kos Administrasi dan Umum $(A \mathcal{E} U)$ perusahaan perbankan, perolehan laba, operating leverage, dan $\mathrm{Cu}$ mulative abnormal returns. Berbeda dengan industri manufaktur, pada perusahaan perbankan tidak dikenal kos pemasaran. Kos admisistrasi dan umum digunakan sebagai proksi kos karena komponen yang ada dalam kos ini mempengaruhi volume aktivitas perusahaan. Volume aktivitas perusahaan perbankan diproksi dengan perolehan laba (Windyastuti, 2013). Perolehan laba diproksi dengan Return on Equity (ROE). Sementara itu, operating leverage merupakan variabel kontrol karena memiliki keterkaitan dengan karakteristik perusahaan (Aboody et al., 2014). Adapun pengumuman laporan laba rugi perbankan diproksi dengan cumulative abnormal returns yang merupakan perbedaan antara return yang terjadi dengan ekspektasi return (Hedberg \& Lindmark, 2013). Selanjutnya operasionalisasi dan ukuran variabel terlihat dalam Tabel 1.

Pengambilan sampel dilakukan berdasar metode purposive sampling dengan kriteria: (1) perusahaan perbankan yang menerbitkan laporan keuangan dari tahun 2002-2014 secara terus-menerus. (2) Perusahaan perbankan yang tidak melakukan merger yang dapat mengubah item-item dalam laporan keuangan. (3) Kos administrasi dan umum tidak melebihi perolehan laba. (4) Data ekstrim atas atau bawah 0,5\% dari distribusi dihilangkan.

Dengan menggunakan metode purposive sampling diperoleh sejumlah 11 (sebelas) bank yang menjadi sampel penelitian. Perusahaan perbankan yang menjadi sampel penelitian ini meliputi: Bank Bali (Bank Permata) Tbk, Bank Central Asia Tbk, Bank Danamon Indonesia Tbk, Bank Internasional Indonesia Tbk, Bank Mayapada International Tbk, Bank Mega Tbk, Bank BNI Tbk, Bank NISP OCBC Tbk, Bank Victoria International Tbk, Bank Artha Graha International Tbk, dan Pan Indonesia Bank Tbk.

Penelitian ini menggunakan metode baru dalam pengukuran kos stickiness di tingkat perusahaan dengan mengacu pada model Weiss (2010). Kos stickiness diukur dengan mengestimasi perbedaan antara besarnya penurunan kos dengan besarnya penurunan volume aktivitas perusahaan dan kese- 
suaian tingkat kenaikan kos dengan kenaikan volume aktivitas perusahaan. Secara matematis kos stickiness dirumuskan sebagai berikut (Ciftci et al, 2013):

$S T I C K Y_{i, t}=\log \left(\frac{\Delta K O S}{\Delta P I_{i, t}}\right)-\log \left(\frac{\Delta K O S}{\Delta P I_{i, \bar{t}}}\right)$

Keterangan:

STICKY = kos stickiness

"KOS = perubahan kos dan dirumuskan sebagai: "KOS= KOS ${ }_{i, t}-K_{i, t-1}$

"PI= perubahan perolehan income dan dirumuskan sebagai: " $P I_{i, t}=P I_{i, t}-P I_{i, t-1}$

$\bar{t} \quad=$ kuartal terakhir terjadinya kenaikan perolehan income

$t_{w} \quad=$ kuartal terakhir terjadinya penurunan perolehan income

$=$ dimensi unit belah silang
STICKY merupakan perbedaan slope fungsi kos antara periode penurunan perolehan laba dan periode kenaikan perolehan laba. Bila kos bersifat sticky berarti kenaikan kos terjadi secara lebih cepat pada saat volume aktivitas meningkat dibandingkan penurunan kos pada saat volume aktivitas menurun dalam jumlah ekuivalen. Nilai STICKY yang negatif menunjukkan bahwa respon manajer terhadap penurunan perolehan laba lebih lemah daripada respon manajer terhadap kenaikan perolehan laba.

Pengukuran akurasi prediksi laba dilakukan dengan menggunakan nilai mutlak kesalahan prediksi laba. Nilai kesalahan prediksi laba merupakan selisih antara $R O E$ yang terjadi pada tahun $t$ dengan nilai prediksi $R O E$ (dilambangkan dengan $\overline{\overline{R O E_{i, t}}}$ ). Kesalahan prediksi laba dituliskan

Tabel 1. Definisi Operasionalisasi Variabel dan Pengukuran Variabel Penelitian

\begin{tabular}{|c|c|c|c|}
\hline Variabel & Proksi & Pengukuran & Acuan \\
\hline $\begin{array}{l}\text { Pengumuman laporan laba rugi } \\
\text { perbankan merupakan perbedaan } \\
\text { antara return yang terjadi dengan } \\
\text { ekspektasi return }\end{array}$ & $\begin{array}{l}\text { Cumulative } \\
\text { Abnormal Returns } \\
\text { (CAR) }\end{array}$ & $R_{i, t}-E\left(R_{i, t}\right)$ & $\begin{array}{l}\text { Hedberg \& } \\
\text { Lindmark, } \\
(2013)\end{array}$ \\
\hline Kesalahan prediksi merupakan & Nilai mutlak & & Weiss (2010) \\
\hline $\begin{array}{l}\text { selisih antara } R O E \text { yang terjadi } \\
\text { pada tahun } t \text { dengan nilai prediksi }\end{array}$ & $\begin{array}{l}\text { kesalahan } \\
\text { prediksi (FE) }\end{array}$ & $\left|R O E_{i, t}-\overline{\overline{R O E_{i, t}}}\right|$ & \\
\hline$R O E$ & & & \\
\hline $\begin{array}{l}\text { Kos stickiness } \\
\text { Merupakan respon kos, secara } \\
\text { asimetrik, terhadap penurunan dan } \\
\text { kenaikan volume aktivitas } \\
\text { perusahaan }\end{array}$ & $\begin{array}{l}\text { Kos stickiness } \\
(\text { STICKY) }\end{array}$ & $\begin{array}{l}\log \left(\frac{\Delta K O S}{\Delta \text { Income }_{i, t}}\right) \\
-\log \left(\frac{\Delta K O S}{\Delta \text { Income }_{i, \bar{t}}}\right)\end{array}$ & $\begin{array}{l}\text { Ciftci et al., } \\
(2013)\end{array}$ \\
\hline $\begin{array}{l}\text { Ketidakpastian lingkungan } \\
\text { Merupakan kondisi lingkungan } \\
\text { perusahaan perbankan yang } \\
\text { sifatnya dinamis }\end{array}$ & $\begin{array}{l}\text { Variasi perolehan } \\
\text { laba (VPI) (dari } \\
\text { kuartal t-3 } \\
\text { sampai t }\end{array}$ & $\frac{\text { Standar Deviasi Income }}{\text { Income Rata - rata }}$ & Weiss (2010) \\
\hline $\begin{array}{l}\text { Variabel kontrol terkait dengan } \\
\text { karakteristik perusahaan }\end{array}$ & $\begin{array}{l}\text { Operating } \\
\text { Leverage (OPLEV) }\end{array}$ & $\frac{\% \Delta E B I T}{\% \Delta I n c o m e}$ & Aboody (2014) \\
\hline
\end{tabular}




\section{Respon Investor terhadap Pengumuman Laba Industri Perbankan yang Menghadapi Kos Stickiness \\ Windyastuti, Kunti Sunaryo, \& Sri Hastuti}

sebagai $F E_{i, t}=R O E_{i, t}-\overline{\overline{R O E_{i, t}}}$. Nilai mutlak kesalahan prediksi laba dituliskan sebagai $A F E_{i, t}=\left|F E_{i, t}\right|$. Untuk menganalisis apakah investor merespon secara lemah terhadap pengumuman laba perusahaan yang menghadapi kos stickiness maka dibangun model dengan meregres cumulative abnormal returns pada variabel kesalahan prediksi laba, kos stickiness, variasi perolehan laba dan karakteristik perusahaan (yang diproksi dengan operating leverage).

$$
\begin{aligned}
C A R_{i, t}= & \gamma_{0}+\gamma_{1} \sum_{j=1}^{k} F E_{i, t}+\gamma_{2} \sum_{j=1}^{k} F E * \operatorname{STICK}_{i, t-j}+ \\
& \gamma_{3} \sum_{j=1}^{k} V P I_{i, t-j}+\gamma_{4} \sum_{i=j}^{k} O P L E V_{i, t-j}+\varepsilon_{i, t}
\end{aligned}
$$

Keterangan:

$$
\begin{array}{ll}
\text { CAR } & =\text { Cumulative Abnormal Returns } \\
\text { FE } & =\text { kesalahan prediksi } \\
\text { STICKY } & =\text { kos stickiness } \\
\text { VPI } & =\text { variasi perolehan laba } \\
\text { OPLEV } & =\text { operating leverage }
\end{array}
$$

\section{HASIL}

\section{Hasil Estimasi}

Agar diperoleh model estimasi sederhana, maka dilakukan reduksi terhadap paramater-paramater yang tidak signifikan melalui pengujian redundant variables. Hasil pengujian menunjukkan bahwa beberapa koefisien regresi memang tidak signifikan sehingga model reduksi dapat digunakan sebagai dasar analisis. Analisis dilakukan berdasarkan model fixed effects dikarenakan hasil pengujian Hausman menunjukkan bahwa model fixed effects lebih unggul daripada random effects. Berdasar model fixed effects, nilai koefisien determinasi $\left(R^{2}\right)$ yang dihasilkan adalah sebesar 0,4037 . Hal tersebut menunjukkan bahwa sebesar 40,37 persen variasi pada cumulative abnormal returns dapat dijelaskan oleh variasi pada variabel-variabel independen, sedangkan sisanya sebesar 59,63 persen dijelaskan oleh residual. Adapun nilai $\mathrm{F}_{\text {hitung }}$ sebesar 7,908 dan signifikan secara statistik. Dengan de-

\begin{tabular}{|c|c|c|c|}
\hline Variabel & Koefisien & $t$-statistik & $\begin{array}{c}t \text {-tabel } \\
(\alpha=5 \%)\end{array}$ \\
\hline Konstanta & 0,602 & $3,700^{*}$ & 1,645 \\
\hline CAR $_{i, t-1}$ & 0,288 & $6,464^{*}$ & 1,645 \\
\hline$F E_{i, t}$ & 0,052 & $4,262^{*}$ & 1,645 \\
\hline $\mathrm{FE}_{\mathrm{i}, \mathrm{t}} * \mathrm{STICK} \mathrm{Y}_{\mathrm{i}, \mathrm{t}}$ & 0,048 & $2,043^{*}$ & 1,645 \\
\hline $\mathrm{VPI}_{\mathrm{i}, \mathrm{t}}$ & 0,034 & 1,571 & 1,645 \\
\hline OPLEV $_{i, t}$ & $-0,595$ & $-2,148^{*}$ & $-1,645$ \\
\hline \multicolumn{2}{|c|}{ Adjusted $R^{2}=0,4037$} & \multicolumn{2}{|c|}{$F_{\text {hitung }}=7,908$} \\
\hline
\end{tabular}
mikian variabel-variabel independen secara serentak berpengaruh signifikan terhadap variabel dependen.

Tabel 2. Hasil Estimasi (Fixed Effects) Model Respon Investor terhadap Pengumuman Laba Industri Perbankan yang Menghadapi Kos Stickiness

*) signifikan pada $(\alpha=5 \%)$

\section{PEMBAHASAN}

Berdasar Tabel 2, maka koefisien regresi cumulative abnormal returns tahun sebelumnya bertanda positif dan signifikan. Hal ini menunjukkan bahwa kenaikan cumulative abnormal returns di masa lalu berdampak pada kenaikan cumulative abnormal returns tahun berjalan. Hubungan antara variabel kesalahan prediksi laba dengan cumulative abnormal returns berbanding lurus. Semakin besar kesalahan dalam prediksi laba, semakin besar pula cumulative abnormal returns. Kesalahan dalam prediksi laba mengindikasikan akurasi prediksi laba. Hal ini berarti semakin besar kesalahan prediksi laba, semakin rendah akurasi prediksi tersebut.

Selanjutnya, apabila faktor kos stickiness diikutsertakan dengan cara melakukan interaksi antara kesalahan prediksi laba dengan kos stickiness, maka respon pelaku pasar terhadap pengumuman laba semakin lemah (koefisien regresi sebesar 0,048$)$. Nilai tersebut lebih rendah dibandingkan nilai yang sama pada saat faktor kos stickiness tidak diikutsertakan. Pada perusahaan yang menghadapi masalah kos stickiness, besaran perubahan 
cumulative abnormal returns akibat perubahan kesalahan prediksi laba lebih kecil daripada perubahan cumulative abnormal returns pada perusahaan yang tidak menghadapi masalah kos stickiness.

Kenaikan kesalahan dalam prediksi laba menunjukkan penurunan akurasi prediksi tersebut. Hal ini menyebabkan laba yang dilaporkan memberikan informasi yang kurang penting bagi prediksi laba periode mendatang. Tingkat kepercayaan investor terhadap laba yang diumumkan berkurang. Semakin tinggi kos stickiness, semakin rendah kepercayaan investor terhadap informasi tentang laba. Pelaku pasar akan merespon dengan lebih lemah pengumuman laba dari perusahaan yang menghadapi kos stickiness. Dengan demikian investor memberikan respon yang lemah terhadap pengumuman laba dari perusahaan yang menghadapi kos stickiness tinggi. Temuan penelitian ini menekankan pentingnya analisis kos untuk memahami perilaku kos termasuk unsur kos stickiness. Peningkatan kemampuan para analisis dalam memahami perilaku kos akan dapat meningkatkan akurasi prediksi pendapatan perusahaan.

Hasil penelitian ini mendukung temuan Weiss (2010) yang menyatakan bahwa investor merespon secara lemah terhadap pengumuman laba pada perusahaan yang menghadapi kos stickiness. Adanya kos stickiness menyebabkan penurunan akurasi prediksi laba sehingga besaran laba yang dilaporkan memberikan informasi yang kurang penting bagi prediksi laba periode mendatang.

Temuan dari penelitian ini juga sejalan dengan temuan Ciftci et al. (2013) yang menyatakan bahwa sering kali para analis kos hanya memahami variabilitas kos dan kos stickiness secara parsial. Hal ini mengakibatkan terjadinya kesalahan sistematis dalam upaya mereka memprediksi besaran laba. Faktor ketidaktepatan informasi tentang perilaku kos, termasuk kos stickiness akan berdampak pada terjadinya kesalahan dalam prediksi laba.
Derajat kos stickiness berasosiasi positif dengan luasnya cakupan pengetahuan para analis kos. Analis kos memerlukan informasi lebih untuk mengatasi masalah ketidakakuratan prediksi laba (Kaspereit, 2016). Untuk itu diperlukan pemahaman terhadap perilaku kos guna meningkatkan akurasi prediksi laba terutama pada saat penjualan mengalami penurunan (Ciftci et al., 2016). Pemahaman yang lebih baik tentang variabilitas kos dan kos stickiness akan meningkatkan ketepatan prediksi laba (Bu et al., 2015). Sebaliknya, kurangnya pemahaman terhadap perilaku kos menyebabkan rendahnya penyesuaian terhadap perubahan kos sehingga menimbulkan kesalahan yang sistematis dalam prediksi kos (Kim \& Prather, 2010).

Selanjutnya variabel variasi perolehan laba tidak signifikan. Hal ini kemungkinan disebabkan pengaruh faktor fluktuasi perolehan laba sudah diwakili oleh variabel kesalahan prediksi laba sehingga pengaruh variasi perolehan laba tidak lagi signifikan. Sementara itu, variabel operating leverage berpengaruh negatif dan signifikan. Hal ini diduga karena rendahnya fleksibilitas penggunaan aktiva tetap sehingga berdampak pada fluktuasi laba dan menurunkan akurasi dalam prediksi laba. Penurunan akurasi prediksi laba akan diikuti dengan penurunan respon investor terhadap pengumuman laba perusahaan. Temuan dari penelitian ini sejalan dengan hasil penelitian Aboody et al (2014) yang menyatakan bahwa tingginya operating leverage berdampak pada future earning yang asimetri. Proses penyesuaian (adjusment) lebih sulit dilakukan pada saat aktivitas perusahaan menurun daripada penyesuaian pada saat aktivitas perusahaan meningkat. Sulitnya proses penyesuaian pada saat aktivitas perusahaan menurun menimbulkan kos stickiness yang selanjutnya berdampak pada timbulnya kesalahan dalam prediksi kos.

Temuan ini berbeda dengan hasil penelitian Hatem (2015) pada perusahaan-perusahaan nonfinansial di Perancis yang menyatakan bahwa leverage tidak berpengaruh terhadap Cumulative $A b$ - 
normal Returns (CAR). Hal ini diduga karena penelitian Hatem (2015) juga mempergunakan variabel perubahan leverage (Aleverage) di samping variabel leverage itu sendiri. Penggunaan dua buah variabel yang hampir sama sebagai variabel penjelas akan menimbulkan multikolinieritas yang menyebabkan variabel leverage tidak berpengaruh signifikan.

\section{SIMPULAN DAN SARAN}

\section{Simpulan}

Penelitian ini bertujuan untuk menganalisis respon investor terhadap pengumuman laporan keuangan sektor perbankan. Berdasar analisis ini akan dapat diketahui apakah investor yang mendapatkan informasi laba akan berperilaku berbeda apabila mengetahui adanya kos stickiness Investor memberikan respon yang lemah terhadap pengumuman laba dari perusahaan perbankan yang menghadapi kos stickiness tinggi. Pada perusahaan perbankan yang menghadapi masalah kos stickiness, akurasi prediksi laba berkurang. Hal ini menyebabkan laba yang dilaporkan akan memberikan informasi yang kurang penting bagi prediksi laba periode mendatang. Tingkat kepercayaan investor terhadap laba yang diumumkan akan berkurang. Semakin tinggi kos stickiness, semakin rendah kepercayaan investor terhadap informasi tentang laba. Pelaku pasar akan merespon dengan lemah pengumuman laba dari perusahaan yang menghadapi kos stickiness.

\section{Saran}

Investor perlu melakukan koreksi terhadap besaran laba yang diumumkan perusahaan perbankan. Apabila perusahaan memiliki derajat kos stickiness tinggi, maka kesalahan prediksi laba relatif besar. Besaran laba yang diumumkan memberikan informasi yang lemah bagi investor. Untuk itu investor perlu melakukan koreksi terhadap besaran laba yang diumumkan perusahaan perbankan.
Operating leverage yang tinggi, di satu sisi memberikan manfaat bagi pemegang saham, akan tetapi di sisi lain menimbulkan risiko kepada manajer akan timbulnya volatilitas pendapatan dan penurunan kinerja perusahaan apabila perekonomian mengalami krisis. Untuk itu manajer perlu menentukan derajat operating leverage dengan mempertimbangkan kondisi perekonomian.

Selanjutnya, keterbatasan model regresi terletak pada ketidakmampuan model tersebut tidak mampu menampung variabel penjelas dalam jumlah besar karena berakibat munculnya multikolinieritas sehingga variabel-variabel penjelas menjadi tidak signifikansi. Untuk itu penelitian berikut dapat mencermati faktor-faktor lain yang diduga memengaruhi respon investor terhadap pengumuman laba seperti unexpected earnings, manajemen laba dan kondisi perekonomian.

\section{DAFTAR PUSTAKA}

Aboody, D., Levi, S., \& Weiss, D. 2014. Operating Leverage and Future Earnings. Working Paper. Anderson School of Management at UCLA.

Anderson, M.R., Banker, R. H., \& Janakiraman, S. 2007. Cost Behavior and Fundamental Analysis of SGA Costs. Journal of Accounting, Auditing $\mathcal{E}$ Finance, 22(1): 1-22.

Banker, R.D., Byzalovy, D., \& Plehn-Dujowichz, J.M. 2011. Sticky Cost Behavior: Theory and Evidence. Working Paper. Temple University.

Bon-Kim, J. \& Wang, K. 2014. Labor Unemployment Risk and Sticky Cost Behavior. Working Paper. City University of Hong Kong.

Bu, D., Wen, C., \& Banker, R.D. 2015. Implications of Asymmetric Cost Behaviour for Analyzing Financial Reports of Companies in China. China Journal of Accounting Studies, 3(3): 181-208.

Ciftci, M., Mashruwala, R., \& Weiss, D. 2013. Do Financial Analysts Recognize Firms' Cost Behavior? Working Paper. SUNY at Binghamton.

Ciftci, M., Mashruwala, R., \& Weiss, D. 2016. Implications of Cost Behavior for Analysts' Earnings Fore- 
casts. Journal of Management Accounting Research, 28(1): 57-80.

Hatem, B.S. 2015. What Determines Cumulative Abnormal Returns? An Empirical Validation in the French Market. International Business Research, 8(12): 89-95.

He, D., Teruya, J., \& Shimizu, T. 2010. Sticky Selling, General, and Administrative Cost Behavior and its Changes in Japan. Global Journal of Business Research, 4(4): 1-10.

Hedberg, P. \& Lindmark, A. 2013. The Possible Beginning of an End: A Study of the Post Earnings Announcement Drift on the Swedish Stock Market. Bachelor Thesis. Uppsala University.

Kama, I. \& Weiss, D. 2010. Do Managers Deliberate Decisions Induce Sticky Costs? Working Paper. Tel Eviv University.
Kaspereit, T. 2016. Asymmetric Cost Behavior and Analyst Earnings Forecasts Revisited: Evidence from a New Firm-year Measure of Cost Stickiness. Paper at Annual Meeting of the American Academic Accounting Association. New York.

Kim, M. \& Prather-Kinsey, J. 2010. An Additional Source of Financial Analysts' Earnings Forecast Errors: Imperfect Adjustments for Cost Behavior. Journal of Accounting, Auditing \& Finance, 25(1): 27-51.

Siringoringo, R. 2012. Karakteristik dan Fungsi Intermediasi Manufaktur di Indonesia. Buletin Ekonomi Moneter dan Manufaktur, 15(1):61-83.

Weiss, D. 2010. Cost Behavior and Analysis Earnings Forecasts. The Accounting Review, 85(4): 1441-1471.

Windyastuti, 2013. Derajat Cost Stickiness Sektor Perbankan dan Pertumbuhan Ekonomi, Jurnal Keuangan dan Perbankan, 8(3): 497-504. 